weakly keeled snail which breeds true. The rate of change from aculeate to smooth, though small, is much higher than that of mutation-rates in general.

The keel in $P$. jenkinsi is produced by a small blunt lobe of the mantle edge which is most conspicuous in aculeate snails.

T. WARWICK

Royal (Dick) School of Veterinary Studies,

University of Edinburgh. Jan. 10.

${ }^{1}$ Boettger, C. R., Arch. Moll., 7\%, 83 (1949).

${ }^{2}$ Boettger, C. R., Arch. Moll., 80, 57 (1951).

${ }^{3}$ Bondesen, P., and Kaiser, E. W., Oikos, 1, 252 (1950).

- Warwick, T., Nature, 154, 798 (1944).

5 EHis, A. E., "British Snails" (Oxf. Univ. Press, 1926).

- Robson, G. C., Brit. J. Exp. Biol., 3, 149 (1926)

'Boycott, A. E., Proc. Mal. Soc., 18, 230 (1929).

\section{Concentric Vascular Bundle in some Ascidial Stalks of Clerodendron infortunatum Gaertn.}

Some ascidial stalks of Clerodendron infortunatum described earlier ${ }^{1}$ contain a few vascular bundles which are concentric-some amphivasal and others amphicribral in structure. The amphivasal vascular bundles are seen near the tip of the ascidial stalk. In tracing the origin of this amphivasal vascular bundle from the base to the tip in serial sections, it was observed that the basal collateral vascular bundle becomes gradually a horse-shoe shaped one which ultimately becomes amphivasal in shape (see photomicrograph). At an upper level this concentric vascular bundle reverts successively to the horseshoe shaped and collateral types. During the transition stage of the vascular bundle from collateral to concentric structure, its upward course is diverted towards the pith. Here the amphivasal vascular bundle is seen embedded within three to six layers of cells of the pith. Next, the concentric bundle turns outward again and takes its place by the side of the neighbouring collateral vascular bundles, by which time it has assumed its collateral form.

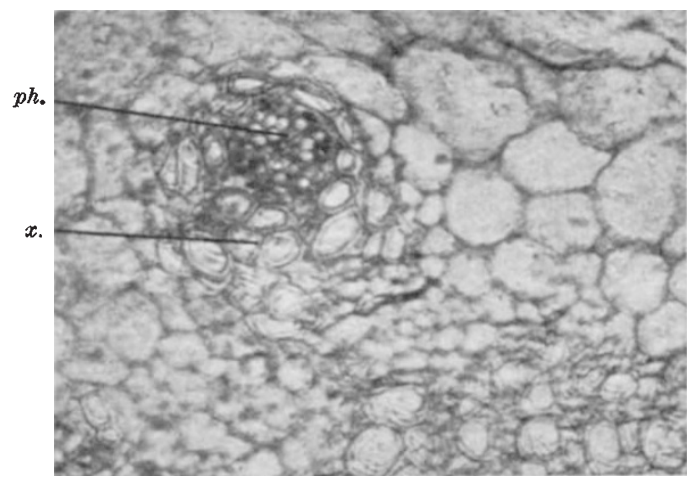

Photomicrograph of an amphivasal vascular bundle. $\times$ c. 150 .

$$
p h ., \text { phloem ; } x \text {., xylem }
$$

The second type of concentric vascular bundle, namely, the amphicribral one, is found near the end of the ascidial stalk, where the bundles are mostly partially or rarely completely concentric. In the petiole of many plants such amphicribral vascular bundles have been noted by Eames and MacDaniels ${ }^{2}$, Metcalfe and Chalk ${ }^{3}$ and Solereder.

The leaf-trace bundles of many monocotyledonous rhizomes and the medullary strands of some dicotyledonous plants are amphivasal ${ }^{6}$. Arber $^{6}$ recorded its occurrence, among others, in the foliage leaves of some monocotyledonous plants. It does not appear to have been recorded before in the petiole of Clerodendron. Fuller details will be published else. where.

I wish to express my thanks and appreciation to Dr. D. M. Bose, director, and to Dr. K. T. Jacob, head of the Department of Botany, of the Bose Institute, for their interest and the latter's helpful criticism in this work.

D. N. Chakraverti

Botany Department, Bose Institute, 93 Upper Circular Road,

Calcutta 9 . Oct. 6.

${ }^{1}$ Chakraverti, D. N., Curr. Sci., 20, 48 (1951).

${ }^{2}$ Eames, A. J., and MacDaniels, I. H., "An' Introduction to Plant Anatomy" (2nd edit, 1947).

${ }^{3}$ Metcalfe, C. R., and Chalk, L., "Anatomy of the Dicotyledons" (Oxford, 1950). "Solereder, H., "Systematic Anatomy of the Dicotyledons" (Eng.
trans., Oxford, 1908).

s Haberlandt, G., "Physiological Plant Anatomy" (Eng. trans., 1914). - Arber, A., Bot. Gaz., 77, 50 (1924).

\section{Transmission of a Nuttallia of a Gerbil by Rhipicephalus sanguineus}

For some years we have been searching for piro. plasms among those local rodents which can be bred in the laboratory. Success in this direction would obviously facilitate work on piroplasmosis and would also provide convenient material for chemotherapeutic studies.

A Nuttallia found in a gerbil, Meriones tristrami, is the nearest approach we have made so far in this direction. This Nuttallia is non-pathogenic for normal animals but becomes pathogenic, though rarely fatal, in splenectomized animals. After splenectomy the parasites multiply until almost 90 per cent of the red cells are infected. The infection becomes chronic with exacerbations of high parasitæmia at various intervals. We have not seen spontaneous cure in animals observed for twelve months. Unfortunately, this piroplasm is not infective for other laboratory animals (very rarely a transient infection is produced in splenectomized mice). This, however, is no great drawback since Meriones tristrami can be bred in the laboratory.

This Nuttallia is readily transmitted by inoculation of whole blood. We have also transmitted it by nymphs of Rhipicephalus sanguineus reared in the laboratory and fed as larvæ on infected animals. It is interesting to note that Rhipicephalus sanguineus, which has been employed extensively in experimental transmission of piroplasms of domestic animals, of Hepatozoon canis and rickettsias of man and animals, really contains two distinct species readily distinguished by the characters of the larvæ and nymphs and the genital aperture of the female. This finding necessitates a revision of some of the accepted data on the transmission of a number of important pathogens.

We may add that Meriones tristrami is frequently parasitized by a Grahamella, which we have transmitted in the laboratory by Homaphysalis otophila.

This work was carried out with the aid of a grant from the Research Council of Israel.

\section{S. ADLER}

Brouria Feldman-MuHsam

Department of Parasitology Hebrew University,

Jerusalem.

Oct. 19. 